\title{
PENGARUH MODEL PEMBELAJARAN KOOPERATIVE TIPE STAD BERBASIS WORKSHEET DYNAMIC GEOGEBRA TERHADAP KEMAMPUAN PENALARAN GEOMETRI SISWA SMA
}

\author{
Oleh: Rahmat, Fahinu \\ Dosen Jurusan Pendidikan Matematika FKIP UHO
}

Email: rahmat_lison@yahoo.com

\begin{abstract}
Abstrak. Penelitian ini bertujuan menganalisis pengaruh peningkatan kemampuan penalaran Geometri siswa yang diajar dengan model pembelajaran kooperatif tipe STAD berbasis worksheet dynamic geogebra, model pembelajaran kooperatif tipe STAD, dan model konvensional di SMA Negeri 1 Sampara, Kabupaten Konawe.

Permasalahan dalam penelitian ini adalah bagaimana perbedaan pengaruh peningkatan kemampuan penalaran Geometri siswa yang diajar dengan model pembelajaran kooperatif tipe STAD berbasis worksheet dynamic geogebra, model pembelajaran kooperatif tipe STAD, dan model konvensional di SMA Negeri 1 Sampara.

Hasil penelitian menunjukkan bahwa Pengaruh model pembelajaran kooperatif tipe STAD berbasis worksheet dynamic geogebra terhadap peningkatan kemampuan penalaran geometri siswa lebih tinggi dibandingkan dengan pengaruh model pembelajaran kooperatif tipe STAD dan model konvensional di SMA Negeri 1 Sampara Kabupaten Konawe.
\end{abstract}

Kata Kunci: Penalaran Geometri, Pembelajaran STAD, Pembelajaran STAD Berbasis Workseet Dynamic Geobegra

\section{PENDAHULUAN}

Salah satu jenis penalaran adalah penalaran geometri. Penalaran geometri merupakan proses mendefinisikan dan mendeduksikan sifat-sifat dari suatu kesatuan geometri dengan menggunakan sifat intrinsik dari kesatuan tersebut, hubungannya dengan kesatuan geometri yang lain, serta aturan-aturan untuk menarik kesimpulan yang benar-benar terjalin antar sifat-sifat yang ada dalam ruang geometri (Euclid) Wing (1985).

Agar siswa mudah memahami penalaran geometri, maka hendaknya proses pembelajaran menggunakan metode yang tepat. Namun kenyataan menunjukkan bahwa penalaran geometri merupakan salah satu penalaran yang sulit dalam matematika. Hal ini sejalan dengan pandangan Maarif (2013) menyatakan kesulitan siswa dalam pembelajaran geometri adalah kesulitan dalam membentuk konstruksi nyata yang diperlukan secara akurat, melukis bangun geometri memerlukan waktu yang lama, dan kesulitan dalam proses pembuktian. Sementara itu, melukis memainkan peranan yang penting dalam pembelajaran geometri di sekolah karena lukisan geometri menghubungkan antara ruang fisik dan teori.

Masalah kesulitan siswa memahami penalaran geometri, umumnya terjadi pada hampir setiap siswa sekolah menengah di Indonesia, termasuk di SMA Negeri 1 
Sampara Kabupaten Konawe. Hal ini dapat dilihat dari hasil observasi awal yang dilakukan oleh peneliti dengan melakukan tes awal dan wawancara terhadap beberapa guru matematika dan siswa SMA Negeri 1 Sampara. Hasil tes awal yang dilakukan dengan memberikan soal penalaran geometri, diperoleh rata-rata capaian penalaran geometri siswa SMA Negeri 1 Sampara sebesar 45.70. Nilai ini tergolong rendah. Rendahnya nilai yang dicapai siswa dalam menjawab soal penalaran geometri menunjukkan bahwa kemampuan penalaran geometri siswa SMA Negeri 1 Sampara masih rendah. Demikian juga dengan hasil wawancara menunjukkan bahwa siswa kurang mampu menjawab soal-soal matematika non rutin, atau soalsoal yang membutuhkan penalaran, khususnya pada penalaran geometri.

Dari permasalahan pembelajaran yang dihadapi di SMA Negeri 1 Sampara, maka salah satu model pembelajaran yang cocok untuk memecahkan permasalahan yang dihadapi adalah pembelajaran berkelompok, mudah dalam mempelajari materi sulit, menarik dan menyenangkan. Model pembelajaran tersebut adalah model Pembelajaran Kooperative STAD Berbasis Worksheet Dynamic Geogebra. Pembelajaran ini diyakini dapat meningkatkan hasil pembelajaran matematika di SMA Negeri 1 Sampara, khususnya meningkatkan kemampuan penalaran geometri siswa.

Ditinjau dari karakteristiknya, pembelajaran Kooperative STAD sebagai model pembelajaran kelompok yang ditunjang suatu media pembelajaran software geogebra yang memungkinkan siswa mencoba sendiri dengan berbagai bentuk dan ukuran bangun geometri. Dengan demikian, maka siswa dapat bernalar dari hasil eksperimen yang dilakukan melalui media yang disiapkan berupa Worksheet Dynamic Geogebra. Melalui software geogebra siswa dapat bereksplorasi dengan bebas ketika memanipulasi sebuah objek geometri, mengubah bentuk, ukuran, jarak, menghubungkan beberapa objek, dan lainlain. Siswa dapat berperan aktif untuk memahami sifat-sifat dari sebuah atau beberapa objek geometri. Selain itu, software ini dilengkapi dengan tampilan yang menarik dan ikon-ikon operasional yang mudah dipahami, sehingga memberi motivasi bagi siswa ketika menggunakannya.

Penelitian ini bertujuan (1) Untuk menganalisis adanya pengaruh peningkatan kemampuan penalaran geometri siswa yang diajar dengan model pembelajaran kooperatif tipe STAD berbasis worksheet dynamic geogebra, model pembelajaran kooperatif tipe STAD 
dan model konvensional di SMA Negeri 1

Sampara.

\section{METODE PENELITIAN}

Penelitian ini merupakan penelitian Quasi Experimental Design yang merupakan pengembangan dari True Experimental Design, dengan pretestposttest control group design. Oleh karena itu pelaksanaannya akan menggunakan siswa kelompok eksperimen dan siswa kelompok kontrol. Kelompok eksperimen terdiri atas dua kelas, yaitu kelas eksperimen pertama dan kelas eksperimen kedua. Pada kelas eksperimen pertama, peneliti memberi perlakuan pembelajaran dengan menggunakan model pembelajaran kooperatif tipe STAD berbasis worksheet dynamic geogebra. Kelompok eksperimen kedua, peneliti memberi perlakuan pembelajaran dengan hanya menggunakan model pembelajaran kooperatif tipe STAD. Pada kelompok kontrol pembelajaran yang diberikan adalah pembelajaran konvensional.

Penelitian ini dilaksanakan di Kabupaten Konawe Provinsi Sulawesi Tenggara pada siswa kelas XI SMA Negeri 1 Sampara. Penelitian ini dilaksanakan pada semester ganjil, tahun pelajaran 2015/2016. Populasi penelitian ini adalah seluruh siswa SMA Negeri 1 Sampara tahun ajaran 2015/2016 dengan populasi target adalah siswa Program IPA kelas XI SMA Negeri 1 Sampara, Kabupaten Konawe.

Sampel pada penelitian ini terdiri dari tiga kelompok siswa kelas XI yang berasal dari Program IPA kelas XI yang dipilih secara purposive random class karena pertimbangan tertentu (Sugiyono, 2010: 300). Penelitian ini mengambil sampel sekaligus populasi bertujuan untuk mendapatkan kelas Program IPA. Hal ini dilakukan dengan pertimbangan kelas yang mempelajari persamaan lingkaran adalah kelas Program IPA yang terdiri dari tiga kelas, yaitu kelas XI IPA 1, kelas XI IPA 2 dan kelas XI IPA 3. Adapun penentuan kelas STAD Geogebra (A1), Kelas STAD (A2) dan kelas Konvensional (A3) dari tiga kelas program IPA dilakukan secara random sederhana.

Data dalam penelitian ini akan dikumpulkan melalui tes, lembar observasi, dan angket skala sikap. Data yang berkaitan dengan penalaran geometri siswa dikumpulkan melalui tes (pretest dan posttest). Sedangkan data yang berkaitan dengan motivasi belajar siswa dikumpulkan melalui angket motivasi belajar matematika dan sikap siswa dalam pembelajaran matematika dengan model STAD dikumpulkan melalui angket maupun lembar observasi siswa. Penalaran geometri diukur berdasarkan Teori Van Hiele yang menyatakan bahwa kemampuan penalaran geometri siswa melalui lima tahap 
perkembangan berpikir dalam belajar geometri. Kelima tahap perkembangan berpikir Van Hiele adalah tahap 0 (visualisasi), tahap 1 (analisis), tahap 2 (deduksi informal), tahap 3 (deduksi), dan tahap 4 (rigor).

Analisis inferensial bertujuan untuk menguji hipotesis penelitian. Data yang digunakan dalam uji hipotesis berbentuk skor Normalized Gain (N-gain). Gain adalah selisih antara nilai posttest dan pretest dibandingkan dengan selisih nilai maksimum ideal dan nilai pretest. Gain menunjukkan peningkatan pemahaman atau penguasaan konsep siswa setelah pembelajaran dilakukan guru. Untuk melakukan uji hipotesis menggunakan uji ANOVA satu arah. Pengolahan data dengan bantuan Microsoft Excel dan program SPSS 20.

\section{HASIL DAN PEMBAHASAN}

Hasil pengujin menggunakan uji anova satu arah untuk uji perbedaan ratarata peningkatan kemampuan penalaran geometri (N-gain) adalah sebagai berikut.

Tabel 1. Tabel anova uji anova satu arah data $\mathrm{N}$-gain tiap kelas perlakuan

\begin{tabular}{|c|c|c|c|c|c|}
\hline \multirow{2}{*}{\multicolumn{6}{|c|}{ Penalaran_Geometri }} \\
\hline & & & & & \\
\hline & $\begin{array}{l}\text { Sum of } \\
\text { Squares }\end{array}$ & $d f$ & $\begin{array}{l}\text { Mean } \\
\text { Square }\end{array}$ & $F$ & Sig. \\
\hline $\begin{array}{l}\text { Between } \\
\text { Groups }\end{array}$ & .154 & 2 & .077 & 10.124 & .000 \\
\hline $\begin{array}{l}\text { Within } \\
\text { Groups }\end{array}$ & .723 & 95 & .008 & & \\
\hline Total & .877 & 97 & & & \\
\hline
\end{tabular}

Berdasarkan hasil uji anova satu arah dapat dilihat bahwa nilai signifikansi untuk uji $\mathrm{F}$ adalah 0.000. Jika dibandingkan dengan $\alpha=0.05$, maka diperoleh bahwa nilai signifikansi $=0.000<\alpha=0.05$. Hal ini berarti Ho ditolak dan terima $\mathrm{H}_{1}$. Dengan demikian maka berarti bahwa terdapat perbedaan rata-rata peningkatan kemampuan penalaran geometri ( $\mathrm{N}$-gain) pada tiga kelas yang diberi perlakuan yang berbeda-beda (kelas yang diberi pembelajaran STAD berbasis worksheet dynamic geogebra (XI IPA 3), kelas yang diberi pembelajaran STAD (XI IPA 1) dan kelas yang diberi pembelajaran biasa digunakan atau metode konvensional).

Karena hasil uji F dalam tabel ANOVA menunjukkan adanya perbedaan rata-rata peningkatan kemampuan penalaran geometri (N-Gain) dari ketiga kelas yang diberi perlakuan berbeda-beda, maka perlu adanya uji lanjutan. Uji lanjutan bertujuan untuk mengetahui kelas yang diberi perlakuan mana saja yang berbeda ratarata peningkatan kemampuan penalaran geometrinya maka dilajutkan dengan Post Hoc Tests. Karena dari hasil uji kesamaan varians, menunjukkan bahwa ketiga kelompok data N-Gain kelas XI IPA 1, XI IPA 2 dan XI IPA 3 semuanya homogen maka jenis analisis dalam Post Hoc Tests yang digunakan adalah adalah uji Tukey HSD. Hasil uji Tukey HSD dapat disajikan dalam tabel Post Hoc Tests berikut. 
Tabel 2. Post Hoc Tests data N-Gain tiap kelas perlakuan

\begin{tabular}{|c|c|c|c|c|c|}
\hline $\begin{array}{l}\text { Depen } \\
\text { Tukey }\end{array}$ & $\begin{array}{l}\text { M } \\
\text { dent Varial } \\
\text { HSD }\end{array}$ & $\begin{array}{l}\text { tiple Com } \\
\text { e: Penala }\end{array}$ & $\begin{array}{l}\text { arisons } \\
\text { an_Geom }\end{array}$ & etri & V-Gain) \\
\hline $\begin{array}{l}\text { (I) } \\
\text { Kelas }\end{array}$ & (J) Kelas & $\begin{array}{c}\text { Mean } \\
\text { Differenc } \\
\text { e (I-J) }\end{array}$ & $\begin{array}{l}\text { Std. } \\
\text { Error }\end{array}$ & Sig. & Ho \\
\hline STAD & STAD & .053939 & .021476 & .036 & Tolak \\
\hline $\begin{array}{l}\text { Geog } \\
\text { ebra }\end{array}$ & $\begin{array}{l}\text { Konvensi } \\
\text { onal }\end{array}$ & $.097127^{*}$ & .021643 & .000 & Tolak \\
\hline STAD & $\begin{array}{l}\text { Konvensi } \\
\text { onal }\end{array}$ & .043187 & .021643 & .119 & Terima \\
\hline
\end{tabular}

Tabel Post Hoc Tests pada tabel 2 menunjukkan bahwa nilai signifikansi untuk uji perbedaan nilai N-Gain kelas pembelajaran STAD geogebra dan Kelas Pemebelajaran STAD adalah 0.036. Nilai signifikansi untuk uji perbedaan N-Gain kelas STAD geogebra dan Kelas Konvensional adalah 0.000 . Nilai signifikansi untuk uji perbedaan rata-rata $\mathrm{N}$-gain kelas STAD dan kelas konvensional adalah 0.119 Jika dibandingkan dengan $\alpha=0.05$, maka dari ketiga kelompok tersebut, yang berbeda secara nyata adalah kelas STAD geogebra dan kelas STAD serta Kelas STAD Geogebra dan kelas konvensional, karena nilai signifikansi $<0.05$, sedangkan untuk kelas STAD dengan kelas konvensional tidak ada perbedaan secara nyata karena nilai signifikansi $=0.119>\alpha=0.05$.

Penelitian ini membandingkan tiga kelas yang diberi perlakuan berbeda-beda. Penentuan kelas eksperimen dan kelas pembanding dilakukan secara acak. Hasil pengacakan dalam memilih dua kelas eksperimen dan satu kelas kontrol diperoleh hasil kelas XI IPA 3 sebagai kelas eksperimen pertama, kelas XI IPA 1 sebagai kelas eksperimen kedua (STAD) dan kelas XI IPA 2 sebagai kelas kontrol (konvensional).

Perlakuan eksperimen diberikan pada kelas XI IPA 3 berupa pembelajaran cooperative STAD berbasis worksheet dynamic geogebra. Pada pembelajaran ini, siswa diperkenalkan dengan software matematika yang disebut dengan geogebra. Untuk memudahkan siswa memahami materi lingkaran, maka siswa disiapkan file aplikasi geogebra materi lingkaran. Dengan file geogebra tersebut, siswa dapat mencoba-coba sendiri, mengulangi sambil bernalar dalam memahami materi lingkaran. Guru hanya mengarahkan diawal pembelajaran tentang bagaimana penggunaan file geogebra lingkaran dan petunjuk pengerjaan LKS berdasarkan file geogebra. Dengan aplikasi geogebra, siswa lebih mudah mengenali dan mengidentifikasi bagian-bagian lingkaran .

Untuk kelas eksperimen kedua (XI IIPA 1), yaitu kelas yang diberi pembelajaran STAD. Pembelajaran pada kelas ini hampir sama dengan pemebelajaran yang diberikan pada kelas XI IPA 3, yang membedakan adalah siswa pada kelas STAD tidak diajarkan dengan bantuan media geogebra. Siswa diberikan 
LKS sebagaimana pembelajaran STAD pada pembelajaran materi lingkaran.

Pada kelas kontrol, yaitu kelas yang diajar dengan model konvensional. Saat penelitian dilakukan pembelajaran yang sering digunakan di SMA Negeri 1 Sampara adalah model pembelajaran langsung. Pembelajaran langsung sering digunakan oleh guru dalam mengajarkan matematika karena mudah, praktis dan dapat mengejar penyelesaian target kurikulum pada tiap semester.

Setelah selesai pembelajaran materi lingkaran dilakukan, maka siswa kembali diberikan evaluasi akhir yang disebut posttest. Pada posttest yang diberikan, semua siswa dari ketiga kelas yang diteliti menunjukkan danya peningkatan dari nilai pretest. Pada hasil posttest, siswa kebanyakan hanya mampu menjawab soal sampai pada level tahapan perpikir analisis, sedangkan untuk tahapan berpikir deduksi informal hanya ada sebagian kecil siswa yang mampu menjangkau, namun tidak sampai tuntas untuk diselesaikan.

Hasil pengujian hipotesis pada taraf signifikansi $5 \%$ berdasarkan kelas menunjukkan bahwa terdapat perbedaan peningkatan kemampuan penalaran geometri (N-gain) antara kelas XI IPA 1, XI PA 2 dan kelas XI PA 3. Peningkatan kemampuan penalaran gometri yang dicapai oleh kelas eksperimen pertama yang diberi pembelajaran kooperative
STAD berbasis worksheet dynamic geogebra melampaui peningkatan kelas eksperimen kedua (kelas STAD) dan kelas konvensional). Hal ini menunjukkan bahwa pembelajaran STAD berbasis worksheet dynamic geogebra mempunyai pengaruh yang kuat terhadap peningkatan kemampuan penalaran geometri di SMA Negeri 1 Sampara. Demikian pula jika dibandingkan nilai peningkatan kemampuan penalaran geometri antara kelas yang diberi pembelajaran STAD dengan kelas konvensional, maka kelas yang diberi pembelajaran STAD tetap melampaui kemampuan penalaran geometri yang dicapai oleh kelas konvensional. Ini menunjukkan bahwa pembelajaran STAD yang didukung dengan penggunaan media geogebra sebagai media untuk memudahkan siswa memahami materi yang bersifat penalaran perpengaruh kuat terhadap kemampuan penalaran geometri pada siswa SMA Negeri 1 Sampara.

\section{KESIMPULAN}

Pengaruh model pembelajaran kooperatif tipe STAD berbasis worksheet dynamic geogebra terhadap peningkatan kemampuan penalaran geometri siswa lebih tinggi dibandingkan dengan pengaruh model pembelajaran kooperatif tipe STAD dan model konvensional di SMA Negeri 1 Sampara. 


\section{DAFTAR PUSTAKA}

Arikunto, S. 2002. Prosedur Penelitian Suatu Pendekatan Praktek. Jakarta: Rieneka Cipta.

Djamarah, S. B. 2002. Psikologi Belajar. Rineka Cipta. Jakarta.

Herdian. 2010. Kemampuan Penalaran Matematika. Diakses http://herdy07. wordpress.com/2010/05/27/kemampu an-penalaran-matematis. Desember 2013].

Ismail. 2003. Media Pembelajaran (Model-model Pembelajaran). Jakarta: Proyek Peningkatan Mutu SLTP.

Joubert, M. (Ed.) 2009. BSRLM Geometry working group: tasks that support the development of geometricreasoning at KS3. Proceedings of the British Society for Research into Learning Mathematics $29 . \quad$ Diakses http://www.bsrlm.org.uk/IPs/ip293/BSRLM-IP-29-3-20.pdf . [15 Juni 2013]

Kadir. 2010. Penerapan Pembelajaran Kontekstual Berbasis Potensi Pesisir Sebagai Upaya Peningkatan Kemampuan Pemecahan Masalah Matematik, Komunikasi Matematik, dan Keterampilan social Siswa SMP. Disertasi Doktor pada SPs UPI Bandung. Tidak diterbitkan.

Maarif , S. 2013. Aplikasi Software Cabri Geometri Pada Materi Geometri Sebagai Upaya Mengeksplorasi Kemampauan Matematis Prosiding Seminar Nasional . ISSN 9772338831. Volume 1, Tahun 2013. Bandung : STKIP Siliwangi. Hal 261. Tersedia di: (Diakses tanggal 12 Januari 2014).

Mateya, M. 2008. Using The Van Hiele Theory to Analyse Geometrical Conceptualisation in Grade 12 Students : A Namibian Perspective. Submitted in partial fullfilment of the requirements for the degree of master of education (mathematics education). Diakses
http://eprints.ru.ac.za/1639/2/MateyaMEd-TR09-80.pdf [06 Februari 2013].

Shadiq, F. 2012. Penalaran atau Reasioning. Diakses www.Fadjarshadiq/PenalaranReasioning. [20 Desembber 2013].

Slavin, R. E. (1995). Cooperative learning. Theory, Research and Practice. Second Edition. Boston: Allyn and Bacon.

Sugiyono. 2010. Metode Penelitian Pendidikan. Bandung : Alfabeta.

Wing M. J. 1985. Geometric Reasoning A New Paradigm For Processing Geometric Information. Diakses: http://www.cs.cmu.edu/ wing/publica tions/CMU-CS-85-144.pdf. [15 Juni 2013]. 